\title{
A critical reflection on the conceptual and legal foundations of the duty to prevent torture
}

\begin{abstract}
The present article elaborates on the legal and normative foundations of the duty to prevent torture. It argues that the content of this duty is both deceivingly simple and complex. The duty, as currently understood, requires States to take a range of legislative, administrative, and judicial measures to prevent acts of torture. However this range of measures and approaches opens the door to endless scenarios of potential relevance, that somewhat blur the content of the duty itself. In order to circumscribe and clarify the nature and scope of the duty it is argued that, firstly, it is necessary to sever the concept of prevention from the definitional elements on which the concept of prohibition of torture is premised and to focus on the conditions known to generate a risk of torture, namely those associated with deprivation of liberty. Secondly, the article suggests that by locating the duty to prevent in a positive obligation framework, more specifically in the positive obligation 'to fulfil', the general duty can be distinguished from the measures through which the former is actually fulfilled. The article suggests that such an approach would facilitate the anticipatory potential of the prevention of torture and allow thinking more broadly about implementation strategies to eradicate torture.
\end{abstract}

Keywords: torture, deprivation of liberty, prevention, prohibition, positive obligations

"You've forgotten that we, whatever we might be, are at this moment in relation to you at least free men, and that's no mean superiority"

The trial, F Kafka

\section{Introduction}

The right to be free from torture and other forms of ill-treatment is a fundamental human right recognised and enshrined in a significant number of international conventions and treaties. ${ }^{1}$ This right entails a set of corresponding duties upon States to prohibit and, this paper argues, to prevent acts amounting to torture or ill-treatment. However while the legal construction of the concept of prohibition of torture has received, and rightly so, much of the judicial, and advocacy attention, ${ }^{2}$ as well as the intellectual thrust of authoritative and highly respected academic work, ${ }^{3}$ the duty to prevent torture, has remained relatively under-explored and, arguably, under-conceptualised. This is not to say that 'torture prevention' as a general concept lacks a sufficient degree of recognition or support among international agencies or national actors tasked with combatting torture and other forms of ill-treatment. Indeed the adoption of international procedural instruments like the European Convention for the Prevention of Torture and Inhuman or Degrading Treatment or Punishment (ECPT) and the Optional Protocol for the Prevention of Torture (OPCAT) are a clear acknowledgement of the importance of prevention as a strategic approach in the fight against torture. Furthermore the mechanisms set up under these Conventions together with international agencies and nongovernmental organisations (NGOs) have produced, over the years, a rather copious and comprehensive range of policy and guidance documents laying down 'guidelines', 
'measures', and 'approaches' aimed at preventing the occurrence of such inhuman and degrading practices. ${ }^{4}$ But what the present paper suggests is that these developments have fallen short of, or perhaps even consciously avoided, the crucial task of developing and elaborating on the legal definition and normative building blocks of a general duty to prevent. In many ways, it could be argued that 'torture prevention' has emerged at a policy level without much elaboration on the legal foundations of the rather complex, if coherent, edifice of measures, guidelines, and recommendations aimed at curbing and preventing the abhorrent practice of torture. The article argues in section 2 that even the, few and sparse, attempts to elaborate in a more coherent fashion on a 'duty to prevent' torture, have been partly limited by the extensive hinging on the, more established but arguably functionally and normatively distinct, legal and conceptual building blocks underpinning the prohibition's approach to torture. Overall, it could be argued, the definition of the duty to prevent torture has remained the poor relative of the definition of torture prohibition.

The content of the duty to prevent torture is both simple and complex. It is simple insofar as it requires States to take effective legislative, administrative, judicial or other measures, some of which are widely acknowledged, to prevent acts of torture. The complexity arises out of the fact that it remains to be defined in what circumstances does this duty arise, what does it entail as a matter of legal obligation, what is the nature of preventive measures. The present article seeks to elaborate on the legal and normative foundations of the duty to prevent torture, understood as a general and autonomous legal obligation imposed upon States. This elaboration is premised on two important analytical steps, that are briefly outlined here and that will be discussed further in sections 4 and 5 below. Firstly, it is argued that the conceptualisation of an autonomous legal duty to prevent requires a change of focus, a move away from the definitional elements on which the concept of prohibition of torture is premised, namely: the intentional infliction of severe pain or suffering, the purpose of the acts, and the official sanction requirement. It will be noted below, in section 2, that some of the existing elaborations on torture prevention are heavily influenced by torture prohibition concepts that are arguably ill-suited to the task of establishing a functional legal duty to prevent, partly because of the different contextual circumstances in which preventive mechanisms may be desirable or necessary. Indeed prevention is not about what has happened but, to state the obvious, is about anticipating and regulating situations where torture may occur, and thus requires the elaboration of forward looking legal obligations as well as policy measures for the containment of situations of risk, rather than backward looking and retrospective culpability tests which are more suitable to the torture prohibition framework. The present article posits that these situations of risk are usually associated with deprivation of liberty and the underlying relationship of subordination between the individual or groups of individuals whose liberty has been curtailed and the authority exercising control. It is in the context of deprivation of liberty that, the article suggest, the duty is triggered.

This article also suggest that a second analytical step necessary to the conceptualisation of an autonomous duty to prevent is connected to the identification of the positive obligation 'to fulfil' as the appropriate positive obligation framework for fleshing out the nature and scope of the duty. It will be argued that whilst in international human rights law there is no general 
duty to prevent, there are explicit treaty based obligations to prevent specific human rights violations. These are usually formulated in action oriented language. For instance Articles 2 and 16 of the United Nations Convention against Torture and Cruel, Inhuman or Degrading Treatment or Punishment (UNCAT) require states to take 'effective' measures to prevent torture and other ill-treatment. While the scope of this might at first appear unclear, section 4 points out that the jurisprudence and practice of a number of international human rights bodies appears to endorse a positive obligation framework. In particular the duty to prevent appears to be filtered through the positive obligation 'to protect'. The article argues that, as a positive obligation 'to protect', the duty arises in reaction to imminent or actual risks rather than in situations generally associated with risk of ill-treatment. The effect is that prevention of ill-treatment remains largely reactive rather than pre-emptive. However it is submitted that when elaborated through the theoretical prism of the positive obligation 'to fulfil' the dynamic and open-ended nature of the general duty to prevent torture is acknowledged revealing its anticipatory potential. At the same time the framework helps to distinguish and avoid conflating the general duty with discrete legal obligations with a preventive potential. These may indeed contribute towards the fulfilment of the general duty but they are a tool to an end. As an ongoing and fluid obligation the implications of the general duty to prevent torture go well beyond a set of legal obligations and may encompass endless types of measures which need to be evaluated in each specific context and against a set of explicit parameters. Framing the duty to prevent through a positive obligation 'to fulfil' approach not only brings greater conceptual and normative clarity, it also allows thinking more broadly about new implementation measures and strategies to eradicate torture and other ill-treatment whilst restoring the individual to his rightful rights-bearer status.

In pursuing these two sets of arguments, the following section 2 begins by providing a brief reconstruction of the prominence of the prohibition of torture framework, and of its dominance over the, admittedly quite limited, attempts and elaborations of the duty to prevent. Section 3 provides a critical reconstruction of the reasons justifying a distinct approach in the conceptualisation of the two distinct duties to prevent and to prohibit torture. Sections 4 and 5 examine the legal and normative dimension of the duty to prevent as a positive obligation. Here the article seeks, on the one side, to conceptualize and to develop the abstract general duty and, on the other side, it seeks to illustrate how the duty to prevent torture translates into operational measures, be these legal obligations, standards or policy measures. Finally, section 6 concludes.

\section{The prominence of the prohibition of torture}

The prohibition of torture is considered, and rightly so, a fundamental norm of international law. The ECtHR case Cestaro $v$ Italy $^{5}$ reminds us of the importance of punishing such acts and enacting adequate criminal legislation prohibiting torture in a democratic society in order to hold official state authorities accountable for acts of an 'absolute gravity' ${ }^{6}$ such as those committed during the 2000 G-8 Summit in Genoa and to deter repetition. The battle to outlaw torture and other ill-treatment internationally has been a long one culminating with the adoption of the 1975 UN Declaration against Torture and the 1984 UN Convention against 
Torture, the recognition of the absolute nature of the prohibition and of its customary status under international law. Indeed, as noted in the introductory paragraphs of this article, the prohibition of torture is enshrined in a number of international human rights instruments and is now accepted as a peremptory norm of international law. Under the international prohibition of torture states are required to refrain from committing torture and to investigate, prosecute, and punish those responsible for acts of torture. The breach of the prohibition of torture involves, on the one hand, the establishment of state responsibility and, on the other hand, the establishment of individual penal responsibility. ${ }^{7}$ In both cases the applicable definition of torture and of its constituent elements understandably becomes of crucial importance in determining legal responsibility. ${ }^{8}$

The jurisprudence on cases of torture has been, unfortunately, abundant and the definition of torture has proved to be normatively complex with new definitions emerging in international criminal law instruments and case law from international penal tribunals. ${ }^{9}$ However, as the following sub-sections point out, while the definitional issues so central to the prohibition have come to dominate the debates concerning torture one - possibly unintended consequence has been that the definition of torture and its prohibition have come to influence the understanding of the prevention of torture, even more so, in the absence of a clear understanding of what the duty to prevent ought to entail.

\section{The influence of the prohibition on the prevention of torture}

Article 2(1) UNCAT states that "Each State Party shall take effective legislative, administrative, judicial or other measures to prevent acts of torture in any territory under its jurisdiction". This key provision nominally addresses torture prevention as a separate international legal obligation. Admittedly this action oriented provision is rather vague and in need of further elaboration. However, it is suggested, attempts to do so have ultimately conflated it with the obligation to prohibit torture. In 2008 the Committee against Torture (CAT), the body responsible for implementing the UNCAT, adopted a General Comment clarifying 'the content of the obligation to take effective measures to prevent torture'. ${ }^{10}$ Arguably, this General Comment is illustrative of the dominance of the prohibition framework and of the centrality of the definition of torture with a focus on measures that are in effect functional to the prohibition of torture such as the criminalisation of torture and combating impunity. The comment reads 'States parties must make the offence of torture punishable as an offence under its criminal law, in accordance, at a minimum, with the elements of torture as defined in article 1 of the Convention, and the requirements of article 4'. In paragraph 9 the comment continues:

Serious discrepancies between the Convention's definition and that incorporated into domestic law create actual or potential loopholes for impunity. (...) the Committee calls upon each State party to ensure that all parts of its Government adhere to the definition set forth in the Convention for the purpose of defining the obligations of the State. (...) the Committee emphasizes that elements of intent and purpose (emphasis added) in article 1 do not involve a subjective inquiry into the motivations of the perpetrators, but rather must be objective determinations under the circumstances. It is essential to investigate and establish the responsibility of persons in the chain of command as well as that of the direct perpetrator(s). ${ }^{11}$ 
The comment rather than elaborating on the duty to prevent reiterates the importance of the definitional elements of torture for the purpose of criminalising such acts under domestic legislation. It then provides an open-ended list of effective measures and guarantees ranging from maintaining an official register of detainees, the right of detainees to be informed of their rights to the right to challenge the legality of their detention or treatment. ${ }^{12}$ As some expert commentators have noted, efforts to clarify the content of a legal obligation to prevent torture and/or other forms of ill-treatment have focused on 'elaborating existing legal obligations and highlighting their preventive potential, reinforcing the primacy of the prohibition and seeing prevention as an ancillary measure. Yet torture prevention is not about fulfilling international commitments concerning the prohibition of torture. ${ }^{, 13}$

In 2002 the African Commission on Human and Peoples' Rights adopted the Robben Island Guidelines for the Prohibition and Prevention of Torture (RIG) intended to provide guidance on the implementation of Article 5 (prohibition of torture) of the African Charter on Human and Peoples' Rights. ${ }^{14}$ Interestingly the implementation guide accompanying the Guidelines stresses the existence of the separate but interrelated obligations to prohibit and to prevent torture. ${ }^{15}$ The practical guide goes on to state that 'The obligation to prevent torture means that governments must take positive action' and provides some examples of preventive measures such as 'introducing oversight and monitoring mechanisms; implementing measures to improve conditions of detention, etc. ${ }^{16}$ In spite of this distinction highlighting the proactive nature of the obligation to prevent the Committee for the Prevention of Torture in Africa (CPTA), the monitoring body established to oversee the implementation of the RIG, in a more recent interpretative comment on Article 5 appears, once more, to give prominence to the absolute prohibition of torture and ill-treatment. The Committee stressed, in line with its overall mandate, the intention to develop a series of general comments which 'will significantly strengthen the absolute prohibition of torture and ill-treatment on the continent' ${ }^{17}$ The comment provides a non-exhaustive list of possible general comments to be adopted $^{18}$ but there appears to be no reference to prevention as such, arguably subsuming the latter under the more robust notion of prohibition. This lack of conceptual and normative clarity is not only detrimental in itself but also in terms of the effectiveness of the CPTA's work, which has been described as failing to develop an actual strategy on the prevention of torture and other ill-treatment in Africa. ${ }^{19}$

More generally, the resulting conflation of prevention with the prohibition of torture not only brings confusion with regard to the states' legal obligations, it also limits the way state actors, human rights bodies, civil society, and activists might think about how to get to grips with torture by skewing strategic intervention, with some exceptions, ${ }^{20}$ in favour of legislative reforms for the criminalisation of torture and of fighting impunity through litigation. ${ }^{21}$ As important and valuable as these interventions are, prevention of torture is something more as well as something different from a procedural obligation implementing the prohibition. It might not be sufficient, for example, for a policy paper setting out interrogation techniques simply to refer and remind interrogators of the absolute prohibition of torture and illtreatment if specific safeguards and oversight mechanisms, which can be said to operationalize the duty to prevent, are not in place. ${ }^{22}$ As the Subcommittee for the Prevention 
of Torture (SPT) has authoritatively opined "Whilst the obligation to prevent torture and illtreatment buttresses the prohibition of torture, it also remains an obligation in its own right". ${ }^{23}$ In spite of the recognition of the existence of two separate and autonomous duties the scope, the nature and content of the obligation to prevent torture are still in need of some elaboration. In attempting to do so the article, in the following sections, seeks first to separate the concept of the prohibition from the prevention of torture considering when and in what circumstances the duty to prevent is triggered. Secondly, on the basis of the jurisprudence and practice of various international human rights bodies the article locates the duty to prevent in a positive obligation framework as the most appropriate for conceptualising the nature and content of the general duty to prevent torture. Lastly, the article examines some examples of discrete preventive measures, both legal and not, which illustrate how the general duty might be translated and fulfilled in practice.

\section{Prohibition and prevention: conceptually and legally distinct duties}

Conceptually the duty to prevent and the duty to prohibit torture refer to two different points in time. The duty to prohibit torture is generally engaged in ex post facto situations. Indeed state and/or individual criminal responsibility is engaged once the act(s) has taken place. In this sense it could be said that the prohibition is essentially retrospective or reactive in character. Notwithstanding the fact that deterrence of criminal sanctions may have a preventive effect, this kind of action remains essentially remedial. In stark contrast with this approach, the duty to prevent is, or ought to be, concerned with a state's obligation to take action before torture may occur and irrespective of whether it may occur or not. In this sense the duty to prevent can be said to focus on ex ante facto situations and to be proactive and anticipatory. A meaningful concept of prevention should therefore not focus its attention on the actual acts, but rather on the situations or conditions of risk of torture. Crucially, unlike in the case of the prohibition, the focus is not, or should not be, on characterising certain acts as torture or other forms of ill-treatment. Indeed the legal qualms over whether an act amounts to torture or cruel, inhuman or degrading treatment (CIDT) become largely irrelevant for prevention purposes. As noted by the CAT itself, 'the conditions (emphasis added) that give rise to ill-treatment frequently facilitate torture and therefore the measures required to prevent torture must be applied to prevent ill-treatment' ${ }^{24}$ So the emphasis, in the torture prevention optic, ought to be placed on the conditions of risk, rather than on the acts themselves.

These, as noted in the following subsection, have been traditionally and uncontroversially understood to be associated with deprivation of liberty. Before discussing the duty to prevent it is worthwhile briefly to point out first what deprivation of liberty means and its significance for torture prevention purposes.

\section{Power relations and vulnerability induced by deprivation of liberty}

One only needs to look at the drafting history of the Declaration and the Convention against Torture and the Optional Protocol to realize that prisoners and persons deprived of their liberty were intended to be their primary beneficiaries. ${ }^{25}$ Sir Nigel Rodley, referring to torture as a 'crime of opportunity', rightly notes that "If only by virtue of their powers of detention, law enforcement officers have more opportunity than most to criminally abuse those in their 
charge: these opportunities need[ed] to be restricted or removed." 26 The idea that torture is more likely to occur in detention or similar situations is also endorsed by the definition of torture as a crime against humanity by other instruments, such as the Rome Statute ${ }^{27}$ which requires the victim to be 'in the custody or control of the accused' ${ }^{28}$ The UN Special Rapporteur on torture has endorsed the concept of 'powerlessness' ${ }^{29}$ in the attempt to articulate the contingent unequal power relations between those exercising authority or elements of authority and the individual(s) deprived of their liberty. The very nature of these power relations is understood to induce and entail a status of vulnerability. ${ }^{30}$

Similarly the Courts have emphasised the existence of a 'relationship of subordination' between the person whose liberty is curtailed and the authorities exercising control:

'Given this unique relationship and interaction of subordination between an inmate and the State, the latter must undertake a number of special responsibilities and initiatives (emphasis added) to ensure that persons deprived of their liberty have the conditions necessary to live with dignity and to enable them to enjoy those rights that may not be restricted under any circumstances or those whose restriction is not a necessary consequence of their deprivation of liberty and is, therefore, impermissible' ${ }^{31}$

Arguably, the existence of a 'relationship of subordination' in these specific circumstances and the consequent vulnerability objectively arising from this relationship create an automatic risk assumption. In dealing with this risk States are expected not only to refrain from interfering with the right to be free from torture but also 'to undertake a number of special responsibilities and initiatives'. International human rights law has witnessed an extensive development of various international instruments containing provisions, rules and standards pertaining to the treatment of those deprived of their liberty, mostly in the criminal justice system. ${ }^{32}$ It is worthwhile to note that among these international instruments are those setting up monitoring bodies, such as the European Committee for the Prevention of Torture (CPT) and the Subcommittee for the Prevention of Torture (SPT) ${ }^{33}$ as well as national preventive mechanisms, entrusted with carrying out regular visits to places of detention. However while initially standard setting and monitoring was primarily focusing on prisoners' rights in the criminal justice system its scope has increasingly expanded to include other sites. This expansion has been arguably influenced by the broad definition of deprivation of liberty, as further elaborated in the following subsection.

\section{The definition of deprivation of liberty and the implications in a torture preventive context}

The ECtHR has found that in order to determine whether there has been a deprivation of liberty, 'the starting point must be the specific situation of the individual concerned and account must be taken of a whole range of factors arising in a particular case such as the type, duration, effects and manner of implementation of the measure in question. The distinction between a deprivation of, and restriction upon, liberty is merely one of degree or intensity and not one of nature or substance' ${ }^{34}$ In determining the existence of a deprivation of liberty the courts will typically consider whether someone is under continuous supervision and control and is not free to leave. ${ }^{35}$ This may extend to deprivation of liberty by private individuals or non-state actors. ${ }^{36}$ Similarly Article 4(2) of the Optional Protocol to the Convention against Torture (OPCAT) defines the scope of 'deprivation of liberty' as 
embracing 'any form of detention or imprisonment or the placement of a person in a public or private custodial setting, from which this person is not permitted to leave at will by order of any judicial, administrative or other authority'. ${ }^{37}$

Under such a broad definition deprivation of liberty might take a variety of forms other than classic detention in prison or strict arrest. ${ }^{38}$ 'Places of detention' and 'places where people are deprived of their liberty' may be understood to apply to settings other than traditional ones such as prisons or police cells. The CAT has expressed that 'each State party should prohibit, prevent and redress torture and ill-treatment in all contexts of custody or control, for example, in prisons, hospitals, schools, institutions that engage in the care of children, the aged, the mentally ill or disabled, in military service, and other institutions as well as contexts where the failure of the State to intervene encourages and enhances the danger of privately inflicted harm' ${ }^{39}$ It is not surprising then that a monitoring body such as the CPT has progressively widened the range of places of deprivation of liberty it might visit to include "not only police establishments and prisons, but also psychiatric hospitals, detention facilities for foreigners held under aliens legislation, juvenile and military detention centres and social care homes' ${ }^{40}$ The CPT visiting practice in recent years has developed further to include 'monitoring return flights and examining the treatment of foreign nationals during their deportation by air'. ${ }^{41}$ The OPCAT has also embraced a broad approach to the concept of places of detention and deprivation of liberty which might include the more traditional criminal justice settings as well as other places where people are detained by public order such as immigration centres and psychiatric hospitals. ${ }^{42}$ Possibly these are just some examples of 'places' of detention in a list, which can be further extended. This is particularly true if the concept of deprivation of liberty is, as it is suggested, underpinned by the ideas of power relations and control. For example, it is possible to speculate about the increasing promotion of non-custodial measures or community provision as an alternative to detention in the criminal justice system or in psychiatric institutions respectively. While avoiding deprivation of liberty in large institutions as far as possible is possibly one of the most effective means of preventing torture and illtreatment, alternative measures might well raise the issues of power and control exercised in their application. ${ }^{43}$ Therefore, if a duty to prevent torture applies to these other, structurally and spatially spread, 'sites' it then becomes necessary to think how does a preventive system account for these 'new' settings and new class of actors, what new measures, if any, or adjustments are necessary.

The broadening of the range of places of detention also means that the class of individuals deemed to be deprived of their liberty extends beyond that of prisoners in the criminal justice system. This also entails that the objective vulnerability associated with the condition of being deprived of liberty may intersect with the individual's own subjective vulnerabilities and that a shift in focus ought to occur from the actual sites of vulnerability to vulnerability itself. As the UN Sub-Committee for the Prevention of Torture put it 'Although all those in detention form a vulnerable group, some groups suffer particular vulnerability, such as women, juveniles, members of minority groups, foreign nationals, persons with disabilities, and persons with acute medical or psychological dependencies or conditions' ${ }^{44}$ 


\section{The duty to prevent torture and states' positive obligations}

It is thus in the contexts of deprivation of liberty that arguably the duty to prevent torture arises. As already mentioned, the vulnerability induced in such settings creates an automatic risk assumption. But what does the duty to prevent entail as a matter of legal obligation? Admittedly this is less clear. While under international human rights law there is no evidence of a general obligation 'to prevent' there are some explicit treaty-based obligations to prevent human rights violations. ${ }^{45}$ However none of these international instruments provide a clear definition of what an obligation to prevent means, some refer to a state's obligation to take "appropriate" 46 and/or "necessary" 47 measures in order to prevent human rights violations. Similarly Articles 2 UNCAT and Article 8(2) of the 2004 Arab Charter on Human Rights place upon the ratifying state an obligation to take 'effective measures' to prevent acts of torture. ${ }^{48}$ The duty is arguably formulated in action-oriented language. Rather than an obligation for states actually to succeed in preventing torture ${ }^{49}$ it appears to place a positive obligation upon the state to take action.

It is broadly acknowledged today in both doctrinal work and jurisprudence that human rights guarantees entail both negative and positive obligations. As noted by Fredman a right carries with it three correlating types of obligations: the negative obligation to avoid or refrain from depriving individuals of their rights, the positive obligation to protect individuals against deprivations of their rights by others, and the positive obligation to fulfil or enable the right holders' access to and effective enjoyment of human rights. ${ }^{50}$ Accordingly the right to be free from torture carries with it its own correlating types of obligations. Under the obligation to respect, a state has a duty not to interfere with the right and this is formulated in the language of the prohibition. The obligation might encompass a subset of procedural obligations whereby the state is required to take specific measures to criminalize, investigate and prosecute any acts of torture. As already argued, these are essentially functional to the prohibition. Under the obligation to protect a state has a duty to protect in specific circumstances against the threat or interference by individuals other than state officials, and under the obligation to fulfil the state has a duty to create the conditions whereby individuals or groups of individuals actually enjoy the right to be free from torture. It is under these latter types of positive obligations that the duty to prevent can be located. As noted in the next section, the jurisprudence of various international courts appears to endorse the idea, in particular, that a duty to prevent the breach of a specific human right is underpinned by the state's positive duty to protect. While this approach can to some extent be seen to support the anticipatory nature of prevention the latter, it is argued, is best served by the positive obligation to fulfil.

\section{The duty to prevent and the positive obligation to protect}

A helpful illustration of the duty to prevent as a positive obligation to protect is the International Court of Justice (ICJ) case Application of the Convention on the Prevention and Punishment of the Crime of Genocide case. In addressing the duty to prevent genocide the Court made the preliminary observation acknowledging the existence of two separate obligations, a negative and a positive one, it noted specifically that: 'The obligation on each 
contracting State to prevent genocide is both normative and compelling. It is not merged in the duty to punish, nor can it be regarded as simply a component of that duty. It has its own scope (...).${ }^{51}$ In defining that scope the Court found that:

it is clear that the obligation in question is one of conduct and not one of result, in the sense that a State cannot be under an obligation to succeed, whatever the circumstances, in preventing the commission of genocide: the obligation of States parties is rather to employ all means reasonably available to them, so as to prevent genocide so far as possible. A State does not incur responsibility simply because the desired result is not achieved; responsibility is however incurred if the State manifestly failed to take all measures to prevent genocide which were within its power, and which might have contributed to preventing the genocide. ${ }^{52}$

In a further passage the Court stated:

a State's obligation to prevent, and the corresponding duty to act, arise at the instant that the State learns of, or should normally have learned of, the existence of a serious risk that genocide will be committed. From that moment onwards, if the State has available to it means likely to have a deterrent effect on those suspected of preparing genocide, or reasonably suspected of harbouring specific intent (dolus specialis), it is under a duty to make such use of these means as the circumstances permit. ${ }^{53}$

Mutatis mutandi, the same approach appears in the ECtHR jurisprudence on failure to take appropriate action to prevent a violation of Article 3.

The obligation imposed on High Contracting Parties under Article 1 of the Convention to secure to everyone within their jurisdiction the rights and freedoms defined in the Convention, taken together with Article 3, requires States to take measures designed to ensure that individuals within their jurisdiction are not subjected to torture or inhuman or degrading treatment, including such ill-treatment administered by private individuals. State responsibility may therefore be engaged where the framework of law fails to provide adequate protection or where the authorities fail to take reasonable steps to avoid a risk of illtreatment about which they knew or ought to have known. ${ }^{54}$

It is evident that in well-defined circumstances, that is where the state is or should be aware of an imminent risk posed by either a private individual or official authority to an individual or a group of individuals, a state has a positive duty to take all reasonable operational measures to protect the individual(s) at risk. ${ }^{55}$ However while the duty to prevent framed through a positive obligation to protect can be said to be narrowly preventive it is still reacting to events which are real and imminent. But is this all there is to prevention? If prevention is about dealing with torture and other-ill-treatment proactively rather than reactively and it is to be of relevance irrespective of whether there is any evidence of torture or ill-treatment actually taking place then the duty to prevent has to go beyond the positive obligation to protect. If the right to be free from torture is to be secured the duty to prevent must go beyond restraint of impending action to include a positive duty to secure the possibility of the right to be free from torture being exercised irrespective of the imminent nature of an existing threat.

\section{The duty to prevent and the positive obligation to fulfil}


It is submitted that for the duty to prevent torture to contribute to a concrete and effective system of prevention, it needs to be understood within a more comprehensive positive obligation framework.

As discussed in the previous sections, the duty to prevent or 'to take effective measures' is largely understood in terms of the positive obligation to protect. In this section it is argued that the duty to prevent is also underpinned by the second type of positive obligation: the obligation to fulfil. The latter broadly requires 'the removal of constraints, as well as the provision of resources or the facilitation of activities which ensure that all are substantively equal in the ability to participate fully as citizens in society. ${ }^{, 56}$ Similarly to the obligation to protect, the obligation 'to fulfil' is also conduct based but rather than intervening in relation to an immediate threat or risk posed by third parties it requires the state to adopt appropriate general measures -legislative, administrative, budgetary, judicial, educational, and other- to facilitate the actual enjoyment of rights.

The rationale for a duty to fulfil is 'that individuals have rights which must be fulfilled' ${ }^{57}$ Just as there are negative and positive duties there are corresponding negative and positive rights, in the latter case, rights to a positive act by the state. ${ }^{58} \mathrm{~A}$ positive right to an act may not necessarily mean access to a specific object but access to enabling arrangements or framework. ${ }^{59}$ The state is to provide this framework and activate it. ${ }^{60}$ The actual content of the framework will depend on the right to be secured and the particular context. Therefore in the case of the prevention of torture the duty to prevent requires that attention be paid to the specific form of deprivation of liberty and the characteristics of the individuals or groups of individuals involved. Clearly arrangements for those detained in immigration centres will be very different from those needed in a psychiatric hospital or in a prison and again these should account for the specific characteristics of the individuals concerned based on age, sex, race, gender, sexual orientation and so forth. As the Subcommittee for the Prevention of Torture has explained the prevention of torture and ill-treatment 'embraces - or should embrace - as many as possible of those things which in a given situation can contribute towards the lessening of the likelihood or risk of torture or ill-treatment occurring. Such an approach requires not only that there be compliance with relevant international obligations and standards in both form and substance but that attention also be paid to the whole range of other factors relevant to the experience and treatment of persons deprived of their liberty and which by their very nature will be context specific' ${ }^{61}$ The framework generated by the action of the State may be made up of a variety of regulatory measures such as action plans, policies, guidelines, institutional arrangements and more, and importantly it should not stop at relevant legal standards.

The contextual, variable and ongoing nature of the positive measures to be put in place highlight the open-ended and dynamic nature of obligation which may lend it to criticism of indeterminacy. ${ }^{62}$ However the relative indeterminacy which positive obligations may display is 'no different from the kind of indeterminacy found in many other legal norms'. ${ }^{63}$ Moreover some general conceptual parameters underpinning and circumscribing the scope of the duty can be identified. Fredman identifies the parameters of: effectiveness, participation, 
accountability and equality. ${ }^{64}$ Effectiveness requires that whatever framework is set up and measures are taken by the State, these must be appropriate and aimed at achieving the right in question. ${ }^{65}$ Secondly, under the participation criterion, measures adopted must enhance the meaningful involvement of those affected by the process. ${ }^{66}$ Generally participation entails the idea of consulting, providing access to information and ensuring the right to express and impart views freely. ${ }^{67}$ Thirdly, accountability requires authorities to be in a position to explain and justify the choice of the actual measures; equally it provides individuals and communities with the opportunity to understand how governments and others have discharged their duty to prevent through different avenues that include, but also go beyond, the traditional judicial process. ${ }^{68}$ Finally, equality requires that in determining the appropriate frameworks the State should be mindful of the fact that these do not exacerbate discriminatory outcomes and that they enable the less advantaged or the most vulnerable sections or groups of society to effectively enjoy individually and collectively their rights. ${ }^{69}$ Importantly, whilst these parameters overlap and reinforce each other 'these criteria are not all-or-nothing standards, but permit degrees of fulfilment' ${ }^{70}$

How the obligation to fulfil and these parameters operate in practice can be seen in an InterAmerican Court case involving a detention facility for minors where torture and ill-treatment actually occurred. The Court found that the state not only had violated its negative duty to prohibit torture and ill-treatment but also that:

the State did not effectively fulfill its role as guarantor of the rights of the child, in this special relationship of subordination between the State and the adult/child deprived of liberty. The State failed to take the necessary positive measures to ensure to all inmates decent living conditions. It also failed to take the special measures of protection that are required of it where children are concerned. ${ }^{71}$

In identifying and recommending the measures to be adopted by the State the Court requested that not only the state introduce all necessary modifications into its domestic legislation, but that it was to do so by elaborating, within six months and in collaboration with civil society, 'a State policy of short, medium and long-term related to children in conflict with the law that is fully consistent with its [Paraguay's] international commitments.' Furthermore, it concluded that state policy must contemplate 'strategies, appropriate actions and the assignation of those resources indispensable for ensuring children deprived of liberty are separated from adults (...) and that integral educational, medical and psychological programs are created for children deprived of liberty'. ${ }^{72}$

The case also suggests that while it is acknowledged that State authorities do have discretion in choosing and prioritizing measures they are expected to exercise that discretion and to take action. Whether that action leads to immediate fulfilment is another matter. It is acknowledged that in some circumstances obligations to fulfil may not be capable of immediate fulfilment, because it might require the state to balance priorities deriving from various norms and principles and because resources might not be available. ${ }^{73}$ Furthermore immediate fulfilment of the duty might be impracticable given that meaningful change on the ground cannot be introduced simply by legislative and administrative authorisation. Change is inevitably also a political process which, in order to be successful, must be 'owned' by the people on the ground. At any rate, even where there are demonstrable resource 
constraints, the state is not relieved of its duty to devise strategies and plans for the fulfilment of the duty. ${ }^{74}$

\section{Positive preventive measures}

As a positive obligation to fulfil, the duty to prevent torture and ill-treatment requires the state to act or put in place a framework that will lessen the likelihood of torture. The duty is triggered whenever the risk of torture might arise. As discussed earlier, this is usually known to be associated with deprivation of liberty. Thus anyone deprived of their liberty, whatever form it may take, has 'a right to a positive act' which translates in the corresponding duty of the state authorities to take any reasonable and necessary measures likely to avert the risk of torture and ill-treatment irrespective of "whether there is any evidence of torture or illtreatment actually taking place'. ${ }^{75}$

The range of measures that could have a preventive impact is in principle limitless and open up a multitude of scenarios. While there might not be any hard and fast rules as to which measures are to be given priority it is clear that the selection and adoption of reasonable preventive measures must take account of the specific context and the issues which appear to be most relevant to the experience of those deprived of their liberty. In doing so the parameters of effectiveness, participation, accountability and equality discussed earlier can provide normative guidance.

It is not the intention of this article to produce a comprehensive compendium of preventive measures, moreover this would be both impractical as well as at odds with the wide-ranging, 'flexible and developmental nature' of preventive measures. ${ }^{76}$ Indeed the effectiveness of preventive measures is commensurate to their flexibility and ability to adapt and respond to the exigencies of changing concrete situations and in response to new problems that gradually emerge in practice. ${ }^{77}$ Hence the following are just examples of broad types of positive measures gleaned from case-law as well as from the practice of some of the international and regional human rights monitoring bodies especially those with a mandate to access and monitor places of detention, ${ }^{78}$ and which illustrate how the general duty to prevent torture might be translated in practice. The next section begins by looking at some of the existing visiting bodies which can be said to be basic institutional mechanisms that ensure that States take their first steps towards greater compliance with the duty to prevent torture and that, once operational, may assist States in moving in the right direction.

\section{Monitoring places of detention}

Visiting mechanisms most notably include the European Committee for the Prevention of Torture (CPT), the UN Subcommittee for the Prevention of Torture (SPT) and the national preventive mechanisms (NPM) established under the OPCAT. ${ }^{79}$ Allowing visits by these international preventive mechanisms and establishing NPMs are legal obligations for those states that have ratified the Convention and/or the Optional Protocol. But these mechanisms can be regarded as well as preventive measures in their own right. Indeed their functioning permits signatories states to engage with their positive obligation by accepting and allowing monitoring visits to places of detention. These monitoring mechanisms provide a useful 
illustration of how preventive mechanisms' work may be guided by Fredman's parameters. It is widely acknowledged that opening up places of detention to external independent scrutiny is one of the most effective ways to prevent torture. ${ }^{80}$ These independent mechanisms produce reports on their visits that enhance state's accountability, their recommendations aim at identifying what is working, what is not, and what needs to be changed. The authorities are also in a position to explain and justify their choices and put in place remedies -such as organizational/institutional improvements, budgeting, policy formulation, and so forth irrespective of potential and subsequent liability in a legal sense. Reports are also an opportunity for individuals and different members of civil society to participate in the process by understanding and actively following-up on those recommendations. Through their visits these mechanisms 'can collect and analyse first-hand information about the situation of persons deprived of their liberty by direct means such as observation, individual and collective interviews with persons in detention and with authorities and NGOs, and from those sources draft a report including practical and contextualized recommendations in order to prevent torture and ill-treatment' ${ }^{81}$ This also leads to the production of general thematic reports casting further attention on specific vulnerable groups and the institutional arrangements affecting them. ${ }^{82}$ However states' acceptance of these monitoring visits and the establishment of domestic national preventive mechanisms under the OPCAT is only the initial or a partial fulfilment of their positive duty to prevent. A number of issues might arise in relation to the effective implementation of the SPT or CPT recommendations, as indeed it is the case for other human rights monitoring bodies, as well as in relation to the effective functioning of the OPCAT national preventive mechanisms, for example, with regards to the scope of their mandate, independence, resources, composition and personnel. ${ }^{83}$ Where issues pertaining to any of these aspects arise, the state is still under an obligation to take action in order to ensure greater conformity with the duty to prevent torture.

\section{General preventive measures}

General preventive measures can also be found in the preventive bodies' recommendations and guidelines dealing with an array of substantive issues. They encompass a wide variety of widely acknowledged procedural safeguards for those deprived of their liberty such as those built around the 'trilogy' of immediate third-party notification, the right of access to a lawyer, and the right to an independent medical examination, accompanied by effective notification of these rights. ${ }^{84}$ Preventive measures also cover the material conditions of detention regimes. ${ }^{85}$ When considering prison overcrowding in the context of article 3 , the ECHR, for example, has encouraged states to act so as to reduce the number of prisoners, including reforming criminal policies and the organization of the prison system, ${ }^{86}$ using more noncustodial punitive measures of freedom, ${ }^{87}$ and minimizing the use of detention. ${ }^{88}$ The practice of preventive monitoring bodies such as the CPT and SPT, have developed recommendations regarding conditions of detention touching on a wide variety of issues, 'including matters relating to physical conditions, the reasons for, and levels of, occupancy and the provision of, and access to, a wide range of facilities and services' ${ }^{89}$ These measures often intersect and adapt to the specific needs of vulnerable individuals. For instance preventive mechanisms have developed guidelines and standards on children and youth covering situations ranging from juveniles in police custody to children in social care 
homes. ${ }^{90}$ During its monitoring visits the SPT has addressed the situation of youth pre-trial detainees and formulated recommendations pertaining to the lock-down hours, the existence of dedicated units as well as the adequacy of the mandate of NPMs in relation to the treatment of minors and juvenile offenders in police custody, immigration or penitentiary institutions. $^{91}$

In mental health institutions, the duty may require a variety of measures, which again go beyond the material living conditions such as adequate physical structures, food and hygiene standards. The UN Special Rapporteur on Torture has recommended banning or reviewing certain treatments and practices and providing appropriate human rights education and information to healthcare personnel to 'promote a culture of respect for human integrity and dignity'. ${ }^{92}$ Among other things, experts have highlighted the need to develop social services structures and systems, including alternatives to institutional care; to review domestic legislation on metal disability laws in light on the Convention on the Rights of Persons with Disabilities ${ }^{93}$ and to consider widening the composition of inspection mechanisms to include service users who 'do see things that the experts do not, and that the detained service users will say things to other service users that they will not say to professional staff' 194

Irrespective of the context or nature of deprivation of liberty the examples above illustrate the fact that the implications of the duty to prevent can be said to be procedural and wide ranging in that the adoption of plans and strategies are to be developed across a period of time, through a multidisciplinary and collaborative approach, and be reviewed and adjusted periodically for the benefit of the most vulnerable. As already argued, identifying and implementing the most appropriate measures should be a participatory effort and process in which domestic authorities, international human rights bodies play a role together with different sections of civil society ranging from independent NPMs, non-governmental organisations (NGOs) with relevant expertise, relevant professional and group associations, to representatives of individuals, the media and so forth. Arguably here lies the challenge for members of civil society and other stakeholders of finding new creative ways of fostering the right to be free from torture. Unsurprisingly in this last respect, civil society's ability to participate meaningfully in the process presupposes rights such as freedom of expression and information and assembly. Therefore, perhaps more surprisingly, preventive measures may well encompass relevant measures that would appear to have limited apparent bearing on torture focusing for example on free media, transparency, accountability and fighting corruption. ${ }^{95}$

\section{Conclusion}

Whilst it might be self-explanatory to suggest that to ensure the right to be free from torture and other ill-treatment the prohibition is not enough and that prevention is equally important, what prevention means in terms of a general legal obligation is less so. The article has attempted to offer an analytical framework that shifts the focus from the definition of acts of torture and other-ill-treatment to the conditions acknowledged to give rise to the risk of 
torture and other ill-treatment. By virtue of their deprivation of liberty and the inherent relation of subordination, individuals are objectively and subjectively vulnerable and action is required to address any risk of torture or ill-treatment, which may or may not have manifested itself, through the adoption of relevant and effective preventive measures. Understood in a broad positive obligation framework and more specifically through the lens of states' positive obligations to fulfil the autonomous duty to prevent torture and ill-treatment finds greater clarity. This in turn can contribute to the effective enjoyment of the right to be free from torture and other ill-treatment. As Fredman argues 'An important advantage of viewing some rights as rights to an act rather than to an object is that, by moving away from the static view of a right as a 'package' of goods transferred to the beneficiary, it also leaves space to move beyond the understanding of the rights-bearer as a passive beneficiary with no say over the nature of the need or the benefit. ${ }^{96}$ The right to be free from torture therefore allows the individual not only to expect that the state will refrain from interfering with her right under the absolute prohibition but also, understood as a positive right, it enables anyone - such as a prison inmate, a psychiatric patient, migrants in detention centres- whose autonomy is curtailed by virtue of a restriction of their liberty, to become a "subject" in a legal relationship rather than the "object" of treatment.

\footnotetext{
${ }^{1}$ Article 5 of the 1948 Universal Declaration of Human Rights (UDHR), Article 7 of the 1966 UN International Covenant on Civil and Political Rights (ICCPR), the 1984 UN Convention against Torture and other Cruel, Inhuman or Degrading Treatment or Punishment (UNCAT), Article 5 of the African Charter on Human and Peoples' Rights (ACHPR), Article 3 of the 1950 European Convention for the Protection of Human Rights and Fundamental Freedoms (ECHR), Article 5 of the 1969 American Convention on Human Rights (AmCHR), Article 8 of the 2004 Arab Charter on Human Rights (ArCHR), Common Article 3 of the four 1949 Geneva Conventions.

2 Amnesty International, 'Conference for the Abolition of Torture - Final Report' (London, 1973).

${ }^{3} \mathrm{~J}$ Burgers and H Danelius, The United Nations Convention against Torture: A Handbook on the Convention against Torture and Other Cruel, Inhuman or Degrading Treatment or Punishment (Dordrecht: Martinus Nijhoff, 1988), M Evans, 'Editorial: Torture', (2006) European Human Rights Law Review 101, M Evans, 'Getting to Grips with Torture', (2002) 51 (2) International and Comparative Law Quarterly 365, M Nowak and E McArthur, The United Nations Convention Against Torture. A Commentary (Oxford University Press, 2008), N Rodley and M Pollard, The Treatment of Prisoners under International Law', $3^{\text {rd }}$ edn (Oxford University Press, 2011), N Rodley, 'The Definition(s) of Torture in International Law', (2002) 55 (1) Current Legal Problems 467.

${ }^{4}$ CAT, 'General Comment No 2: Implementation of Article 2 by States Parties' CAT/C/GC/2 (24 January 2008), SPT, 'The Approach of the Subcommittee to the Concept of Prevention of Torture and Other Cruel, Inhuman or Degrading Treatment or Punishment under the Optional Protocol' CAT/OP/12/6 (30 December
} 
2010), OHCHR, APT and APF 'Preventing Torture: An Operational Guide for National Human Rights Institutions' (2010) http://www.ohchr.org/Documents/Countries/NHRI/Torture_Prevention_Guide.pdf ${ }^{5}$ ECtHR, Affaire Cestaro c Italy, Requête No 6884/11, Arrêt 7 Avril 2015.

${ }^{6}$ Ibid. para 78

${ }^{7} \mathrm{~N}$ Rodley and M Pollard, 'Criminalisation of Torture: State Obligations under the United Nations Convention against Torture, Cruel, Inhuman or Degrading Treatment or Punishment', (2006) 2 European Human Rights Law Review 115.

${ }^{8}$ Ibid.

${ }^{9}$ See N Rodley, 'Reflections on Working for the Prevention of Torture', (2010) 6(1) Essex Human Rights Review 21

${ }^{10}$ CAT, 'General Comment No 2' n 4, para 2

${ }^{11}$ Ibid. para 2

${ }^{12}$ Ibid. para 13

${ }^{13} \mathrm{R}$ Murray, E Steinerte, M Evans, A H de Wolf, The Optional Protocol to the UN Convention Against Torture (OUP, 2011), 61.

14 'Robben Island Guidelines for the Prohibition and Prevention of Torture' ACHPR/ Res. 61(XXXII) 02 (2002) at 7-9.

${ }^{15}$ Association for the Prevention of Torture (APT), 'Robben Island Guidelines for the Prohibition and

Prevention of Torture. A practical Guide for Implementation' (2008), at 7-8 http://www.achpr.org/files/specialmechanisms/cpta/rig_practical_use_book.pdf (accessed March 2016).

${ }^{16}$ Ibid.

17 'Concept paper on the development of a general comment on Article 5 of the African Charter on Human and

Peoples' Rights' ACHPR 2015, at para 8. Available at

http://www.achpr.org/files/news/2015/05/d182/concept_paper.pdf (accessed March 2016).

${ }^{18}$ Ibid. at para 13

${ }^{19} \mathrm{R}$ Murray and D Long 'Ten years of the Robben Island Guidelines and prevention of torture in Africa: For what purpose?' (2012) African Human Rights Law Journal, 346.

${ }^{20}$ Most notably, the European Committee for the Prevention of Torture and the UN Sub-Committee for the Prevention of Torture. Among the NGOs, for example, the work of the Association for the Prevention of Torture (APT) 'Torture Prevention in the law' http://www.apt.ch/en/torture-prevention-in-the-law/ (last accessed March 2016).

${ }^{21} \mathrm{~L}$ Oette, 'Implementing the prohibition of torture: the contribution and limits of national legislation and jurisprudence', (2012) Vol 16 No 5 International Journal of Human Rights, 717.

${ }^{22}$ I Renzulli, 'Ali Hussein v Secretary of State for Defence: what was not said of shouting as a lawful interrogation technique' (2015) October Public Law, 550.

${ }^{23}$ SPT, 'The Approach of the Subcommittee to the Concept of Prevention' $n$ 4, para 1.

${ }^{24}$ CAT, 'General Comment No 2' n 4, para 3.

${ }^{25}$ Burgers and Danelius note 'The history of the Declaration and the Convention (against Torture) make it clear that the victims must be understood to be persons who are deprived of their liberty or who are at least under the factual power or control of the person inflicting the pain' Burgers and Danelius, The United Nations Convention against Torture. A Handbook on the Convention against Torture and Other Cruel, Inhuman or Degrading Treatment or Punishment n3, 120; Rodley and Pollard, The Treatment of Prisoners under International Law n 3. ${ }^{26}$ Rodley, 'Reflections on Working for the Prevention of Torture' $\mathrm{n}$ 9, 16.

${ }^{27}$ UN General Assembly, Rome Statute of the International Criminal Court (last amended 2010), 17 July 1998

${ }^{28}$ Article 7 (2) (e) of the Rome Statute reads: "Torture" means the intentional infliction of severe pain or suffering, whether physical or mental, upon a person in the custody or under the control of the accused'.

${ }^{29}$ Nowak, 'What Practices Constitute Torture?: US and UN Standards', (2006) Vol 28 (4) Human Rights Quarterly, 832, M Nowak \& E McArthur, 'The distinction between Torture and Cruel, Inhuman and Degrading Treatment', (2006) 16 (3) Torture, 147.

30 'Persons held in captivity, be it in police custody, remand facility or prison, or deprived of their liberty in any other context, find themselves in a situation of complete dependency and are therefore particularly vulnerable to any abuse'. 'Report of the Special Rapporteur on torture and other cruel, inhuman or degrading treatment or punishment' UN doc A/HRC/13/39/Add.5 (5 February 2010), at para 37.

${ }^{31}$ Inter-American Court of Human Rights, "Juvenile Reeducation Institute" v Paraguay (Panchito Lopez), Series C No. 112, Judgment of September 2, 2004, paras152- 153; ECtHR, Affaire Torreggiani et Autres c Italie, Requêtes Nos 43517/09, 46882/09, 55400/09, 57875/09, 61535/09, 35315/10 et 37818/10, Arrêt 8 Janvier 2013, at para 94. The UN Working Group on Arbitrary Detention (WGAD) has pointed out that 'The main element that defines deprivation of liberty is the inability of those who are in detention to defend and protect themselves, as their daily life is largely dependent on the decisions taken by the staff at the detention facilities' 
WGAD, 'Report of the Working Group on Arbitrary Detention' UN doc A/HRC/10/21 9 (16 February 2009), para 46.

${ }^{32}$ A non-exhaustive list of standards would include: The Standard Minimum Rules for the Treatment of Prisoners ECOSOC Res 663c (XXIV) (31 July 1957), amended by ECOSOC Res 2076 (LXII) (13 May 1977); Code of Conduct for Law Enforcement Officials, GA Res 34/69 (17 December 1979); Principles of Medical Ethics relevant to the Role of Health Personnel particularly Physicians, in the Protection of Prisoners and Detainees against Torture and other Cruel and Inhuman, Degrading Treatment or Punishment, GA Res 37/194 (18 December 1982); Body of Principles for the Protection of All Persons under Any Form of Detention or Imprisonment GA Res 34/173 (9 December 1988); Basic Principles for the Treatment of Prisoners, GA Res 45/111 (14 December 1990); Rules for the Protection of Juveniles Deprived of their Liberty, GA Res 45/113 (14 December 1990).

${ }^{33}$ Article 1 of OPCAT sets out the objective of the instrument as being 'to establish a system of regular visits undertaken by independent international and national bodies to places where people are deprived of their liberty' ${ }^{34}$ ECtHR, Guzzardi v Italy, Application No 7367/76, Judgment of 6 November 1980, para 92.

${ }^{35}$ ECtHR, $H L v U K$, Application No 45508/99, Judgment of 5 October 2004, para 91. P (by his litigation friend the Official Solicitor) (Appellant) v Cheshire West and Chester Council and another (Respondents) [2014]

${ }^{36}$ ECtHR, Rantsev v Cyprus and Russia, Application No 25965/04, Judgment of 7 January 2010, paras 314-19

${ }^{37}$ The Inter-American Commission's definition is also very broad. 'Principles and Best Practices on The

Protection of Persons Deprived of Liberty in the Americas' (OEA/Ser/L/V/II.131 doc. 26).

${ }^{38}$ Secretary of State for the Home Department v JJ [2008] 1 AC 385.

${ }^{39}$ CAT, 'General Comment No 2' n 4, para 15.

${ }^{40}$ Council of Europe, 'The CPT at 25: taking stock and moving forward' Background paper Conference, 2

March 2015, Strasbourg - France, at 2.

${ }^{41}$ Ibid.

${ }^{42}$ Murray and others, The Optional Protocol to the UN Convention Against Torture n13, 46.

${ }^{43}$ For example, the United Nations Standard Minimum Rules for Non-custodial Measures (Tokyo rules) General Assembly UN Doc A/RES/45/110 (14 December 1990) mention the role of community and volunteers in the application of the non-custodial sentences (Articles 17-19).

${ }^{44}$ Guiding principle 5(i) in SPT, 'The Approach of the Subcommittee to the Concept of Prevention' supra n 4

${ }^{45}$ The Convention on the Elimination of all Forms of Racial Discrimination (CERD) refers in its Preamble to all the necessary measures needed to prevent 'racist doctrines and practices'; Art 2(b)(e) of the Convention on the Elimination of all Forms of Discrimination Against Women (CEDAW) refers to an obligation to pursue a 'policy of eliminating' discrimination through the adoption of 'appropriate legislative and other measures'; the Arts 6, 23 and 24 of the Convention for the Protection of All Persons from Enforced Disappearances (CAED) place obligations upon the ratifying state to adopt 'necessary measures' to prevent enforced disappearances.

${ }^{46}$ Arts 2 and 11(2) CEDAW, Art 2 CERD.

${ }^{47}$ Preamble CERD, Arts 6, 12, 22 CAED.

${ }^{48}$ Also Art 15(2) of the Convention on the Rights of Persons with Disabilities 2006 (A/RES/61/106) reads "States Parties shall take all effective legislative, administrative, judicial or other measures to prevent persons with disabilities, on an equal basis with others, from being subjected to torture or cruel, inhuman or degrading treatment or punishment".

${ }^{49}$ Murray and others, The Optional Protocol to the UN Convention Against Torture n13, 58.

${ }^{50}$ While there are different theories concerning the categorization of duties the present discussion uses as an analytical tool the tripartite typology of the obligations to respect, protect and fulfil as expounded in the work of S Fredman, Human Rights Transformed. Positive Rights and Positive Duties (Oxford University Press, 2009). The categorization of duties imposed by human rights obligations was originally identified by H Shue, Basic Rights: Subsistence, Affluence, an US Foreign Policy, (Princeton University Press, 1996). This approach was endorsed by the Maastricht Guidelines on Violations of Economic, Social and Cultural Rights', reprinted (1998) 20 Human Rights Quarterly 691. See also A Mowbray, The Development of Positive Obligations under the European Convention on Human Rights by the European Court of Human Rights (Hart Publishing, 2004). On the categories and scope of obligations arising from human rights and the duty to prevent W Kälin and J Künzli, The Law of International Human Rights Protection (Oxford University Press, 2009), at 96-103-190; O De Schutter, International Human Rights Law (2 $2^{\text {nd }}$ edition CUP, 2014) chapters 4-5.

${ }^{51}$ ICJ, Application of the Convention on the Prevention and Punishment of the Crime of Genocide (Bosnia and Herzegovina v. Serbia and Montenegro), Judgment of 26 February 2007, para 427.

${ }^{52}$ Ibid. para 430.

${ }_{53}^{53}$ Ibid. para 431.

${ }^{54}$ Mahmut Kaya v Turkey, Application No 22535/93, Judgment of 28 March 2000, para115. The Court adopted a similar line of reasoning in the $Z v U K$ case concerning the inhuman and degrading treatment suffered by four 
children at the hands of abusive parents and the failure of the local authority to intervene appropriately. The Court stated that measures should 'include reasonable steps to prevent ill-treatment of which the authorities had or ought to have had knowledge'. ECtHR, $Z v U K$, Application No 29392/95, Judgment of 10 May 2001, para 73.

55 This has been clearly articulated in ECtHR, Osman v United Kingdom, Application No 87/1997/871/1083, Judgment of 28 October 1998, para 115.

${ }^{56}$ Fredman, Human Rights Transformed n 50, 77.

${ }^{57}$ Ibid. 88.

${ }^{58}$ Ibid.

${ }^{59}$ Ibid.

${ }^{60}$ Ibid.

${ }^{61}$ SPT, 'The Approach of the Subcommittee to the Concept of Prevention' n 4, para 3

${ }^{62}$ Fredman, Human Rights Transformed, 77.

${ }^{63}$ Ibid.

${ }^{64}$ Ibid.

${ }^{65}$ Ibid.

${ }^{66}$ Ibid.

${ }^{67} \mathrm{H}$ Potts, Participation and the Right to the Highest attainable Standard of Health (University of Essex Human Rights Centre, 2008).

${ }^{68}$ Fredman, Human Rights Transformed n50, 77

${ }^{69}$ Ibid.

${ }^{70}$ Ibid.

${ }^{71}$ IACtHR, “Juvenile Reeducation Institute” v Paraguay (Panchito Lopez Case) supra n 31 para 176.

${ }^{72}$ Ibid. at paras 316-17.

${ }^{73}$ Fredman Human Rights Transformed n50, 80

${ }^{74}$ Whilst lack or limited resources might be taken into account when considering the level of conformity or compliance with the duty to prevent the state is still under an 'immediate' duty to take measures using its best efforts and taking the matter seriously. The Human Rights Committee made clear that ' $\mathrm{t}]$ reating all persons deprived of their liberty with humanity and with respect for their dignity is a fundamental and universally applicable rule. Consequently, the application of this rule, as a minimum, cannot be dependent on the material resources available in the State party.' HRC, 'General Comment No 9, Humane treatment of persons deprived of liberty (Art. 10)' (30 July1982), at para1. Similarly the Inter-American Court has stated that "the States cannot invoke economic hardships to justify imprisonment conditions that do not comply with the minimum international standards and respect the inherent dignity of the human being." IACtHR, Vélez Loor v Panama, Series C No 218, Judgment of 23 November 2010, para 198, IACtHR, Boyce et al v Barbados, Series C No 169, Judgment of 20 November 2007, para 88.

${ }^{75}$ SPT, 'The Approach of the Subcommittee to the Concept of Prevention', para 5(c).

${ }^{76}$ Murray and Others, The Optional Protocol to the UN Convention Against Torture n13, 62.

77 A Cassese, 'A New Approach To Human Rights: The European Convention for The Prevention of Torture' (1989) 83 Am J Int'l Law, 128-9.

${ }^{78}$ Some examples of monitoring bodies visiting places of detention include the UN Committee against Torture, the UN Special Rapporteur on the Question of Torture, the UN Working Group on Arbitrary Detention, the UN Special Rapporteur on the Human Rights of Migrants, the Special Rapporteur of the Inter-American Commission on Human Rights on the Rights of Persons Deprived of Freedom, the African Committee for the Prevention of Torture (ACPT), the Special Rapporteur of the African Commission on Human and Peoples' Rights on Prisons and Conditions of Detention in Africa, and human rights components of UN peace-keeping operations or OHCHR country offices.

${ }^{79}$ Article 17 of the OPCAT expressly requires that each state signatory should designate a National Preventive Mechanism (NPM). NPMs are national bodies that have the mandate to conduct regular visits to places of detention as well as make recommendations to the state to improve the situation of the persons deprived of their liberty.

${ }^{80}$ N Rodley, 'Reflections on Working for the Prevention of Torture' n 9, 21.

${ }^{81}$ Eighth annual report of the Subcommittee on Prevention of Torture and Other Cruel, Inhuman or Degrading Treatment or Punishment CAT/C/54/2 (26 March 2015), para 64.

82 On issues relating to detention of lesbian, gay, bisexual, transgender and intersex persons see for example: Eighth annual report of the Subcommittee on Prevention of Torture and Other Cruel, Inhuman or Degrading Treatment or Punishment CAT/C/54/2 (26 March 2015) at para 66-72. See also CPT Standards, CPT/Inf/E (2002) $1-\operatorname{Rev} 2010$ covering a number of thematic areas. 
${ }^{83}$ SPT, 'Guidelines on National Preventive Mechanisms' CAT/OP/12/5 (9 December 2010). See further Murray and others, The Optional Protocol to the UN Convention Against Torture n13, chapter 6.

${ }^{84}$ CPT, 'CPT Standards. "Substantive" sections of the CPT's General Reports' (Council of Europe, 2015)

CPT/Inf/E (2002) 1-Rev 2010. Report on the visit of the Subcommittee on Prevention of Torture and Other

Cruel, Inhuman or Degrading Treatment or Punishment to Mali CAT/OP/MLI/1 (20 March 2014) paras 16-24;

Report on the visit of the Subcommittee on Prevention of Torture and Other Cruel, Inhuman or Degrading

Treatment or Punishment to Sweden CAT/OP/SWE/1, para 43. 'General Comment No 2' supra n4 para 13.

${ }^{85}$ CPT/Inf/E (2002) 1-Rev 2010; R Morgan and M Evans, Combating Torture in Europe: the Work and

Standards of the CPT (Strasbourg: Council of Europe Press 2001; M Murdoch, The Treatment of Prisoners-

European Standards (Strasbourg: Council of Europe Press, 2006); 'General Comment 2' n 4, para 13.

${ }^{86}$ Torreggiani v Italy n 31, para 95.

${ }^{87}$ ECtHR, Norbert Sikorski c Pologne, Requête No17599/05, Arrêt 22 January 2010, para 158.

${ }^{88}$ ECtHR, Ananyev and Others v Russia, Applications Nos 42525/07 - 60800/08, Judgment of 10 January 2012, para 98 and para 197.

${ }^{89}$ SPT, 'The Approach of the Subcommittee to the Concept of Prevention'n 4, para 5(d).

${ }^{90} \mathrm{CPT}$, 'The CPT at 25 ' $\mathrm{n}$ 40, 16-20.

91 'Report on the visit of the Subcommittee on Prevention of Torture and Other Cruel, Inhuman or Degrading

Treatment or Punishment to New Zealand' CAT/OP/NZL/1 (28 July 2014), at para 16 and 26.

${ }^{92}$ Report of the Special Rapporteur on torture and other cruel, inhuman or degrading treatment or punishment,

UN Doc A/HRC/22/53 (1 February 2013)

${ }^{93}$ P Bartlett 'Implementing A Paradigm Shift: Implementing the Convention on the Rights of Persons with

Disabilities, in the Context of Mental Disability Law' in Center for Human Rights \& Humanitarian Law Anti -

Torture Initiative, Torture in Healthcare Settings: Reflections on the Special Rapporteur on Torture's 2013

Thematic Report (American University Washington College of Law, March 2014) available

https://www.wcl.american.edu/humright/center/resources/publications/documents/YESPDF_Torture in Healthc are Publication.pdf (last accessed March 2016).

${ }^{94}$ P Bartlett, 'The CPT and Mental Disability: The Next 25 Years' in Council of Europe, The CPT at 25 Years, n 40

${ }^{95}$ Seventh annual report of the Subcommittee on Prevention of Torture and Other Cruel, Inhuman or Degrading Treatment or Punishment CAT/C/52/2 (20 March 2014), paras 72-86.

${ }^{96}$ Fredman, Human Rights Transformed n 50, 90 